UDC 785.7:784.5

\title{
CHAMBER CANTATAS OF OLEH KYVA: STYLE EVOLUTION OF GENRE
}

\author{
Nataliia Pertsova ${ }^{1 a}$, Viktoriia Shevchenko ${ }^{2 a}$ \\ ${ }^{1}$ Associate Professor; ORCID: 0000-0003-4575-7691; e-mail: natalia.pertsova@gmail.com \\ ${ }^{2}$ Associate Professor \\ ${ }^{a}$ Kyiv National University of Culture and Arts, Kyiv, Ukraine
}

\begin{abstract}
The aim of the study is to identify the characteristic traits of Oleh Kyva's composer's thinking on the example of his chamber cantatas. This goal presupposes the solution of a number of tasks, in particular, an analysis of the place of his work in the context of musical culture of the second half of the twentieth century and the allocation of its links with the previous musical tradition.

The research methodology is connected with the use of the method of analysis of the available musical material - the cantata of O. Kyva, the review of the scientific and theoretical material devoted to the composer's work. The synthesis and systematization of the results in order helped to identify the general and distinctive features of the Kyva's cantatas.

The scientific novelty is to shed light on the key features of Oleh Kiva's choral thinking, which are evident in his chamber cantatas. Synthesis of various genre origins and a bright melodic beginning are the features that form the basis of the author's compositional style. The vitality of the cantata genre in 20th century music culture and its ability to reproduce composer's intentions are affirmed.
\end{abstract}

Results. Chamber cantata is one of the leading genres in the work of A. Kyva. One can note the evolution of composer's thinking on the example of his chamber cantatas. In this genre there is a change in composing thinking - from the prevalence of lyrical images in the first chamber cantatas to philosophical and in-depth contemplation in the latter.

Conclusions. The composer has a tendency to stylistic synthesis, which manifests itself through the combination of elements of academic and pop music, folk native music and oriental ethnic music. Each chamber cantata represents a new version of the realization of this genre and testifies to the extraordinary melodic talent of the composer. A promising direction for further research is to highlight the specifics of this genre's embodiment in the works of other leading Ukrainian composers.

Keywords: chamber cantatas; Oleh Kyva; style; evolution; lyrics

\section{Introduction}

Significant interest to vocal beginning is one of the main features of domestic composers' creation. Lot of attention in their heritage is paid to different vocal and 
instrumental genres. Oleh Kyva is a composer who created a lot of chamber cantatas and each became a real treasure of domestic art. Although the specific of this composer's creation gained scientific foundation there are many questions need to be analyzed deeper.

O. Komenda's work "Chamber cantata in the Ukrainian music of the 2 nd half of the twentieth century. Main trends and trends of the genre" highlights general trends and dynamics of cantata genre development in the context of the Ukrainian music of XX century. H. Manokina's dissertation "The problem of cycling in the genre of chamber cantata (on the example of Elena Firsova's works) investigated the issue of parts combining in the frameworks of cycle works in general and in the chamber cantata in particular. Survey of chamber cantata as a genre in the domestic field is made by $\mathrm{M}$. Yarko in "Ukrainian chamber cantata: the invariant of genre form" monograph. "Evaluation of music beauty" by G. Lunina highlights general features of O. Kyva's creation. O. Vasylenko's article "Features of the genre of Oleh Kyva chamber cantata in the context of contemporary composer quest" analyses specific cantata genre in Kyva's creation.

At the present time the creative heritage of Ukrainian composers worked at the end of $X X$ and beginning of $X X I$ centuries still remains poorly investigated. That is why it is the appropriate field for scientific researches. In particular, in modern study of art there are no systematic results to highlight 0 . Kyva's composer's thinking in his cantata creativity.

\section{The purpose of the article}

The underlining of characteristic features of Oleh Kyva composer's thinking on the example of his chamber cantatas is the aim of investigation. This aim foresees the decision of some tasks, and, in particular, to analyze the place of his creation in the context of music culture of the second half of XX century and to highlight his links with previous music tradition.

\section{Presentation of the main material}

Oleh Kyva is the composer who gave the advantage to the pieces connected with vocal beginning. There are instrumental pieces in his heritage - preludes and other chamber pieces for piano, concerts, suites, sonatas, ballet, symphonies, but rather often it is the only embodiment of particular genre. There are much more vocal and instrumental pieces, chamber (like romances and songs) as well as broad-scale (like cantatas for choir and also cantatas for voice and orchestra, choirs). Such returning to one and the same genre cantata - gives the possibility to talk about it main position in composer's creation.

Oleg Kyva was born on January 5, 1947, and his creative way was connected with traditional steps characteristic to the composers of XX century. First, he studied at music school in Poltava, than he studied in Poltava musical college, where he started to pay attention to the art of composing. In Kyiv State Conservatory named after P. I. Chaikovsky (from 1995 Petro Tchaikovsky National Music Academy of Ukraine) Oleh Kyva studied composing in the class of Myroslav Skoryk the master of Ukrainian 
composing art. After graduation in 1971 Kyva started to teach, than he was a musical editor before he concentrated his attention on creation work.

Kyva composer's style is connected with continuation of romance traditions. Lyric nature of melody and attention to vocal beginning led to the great number of music for movies. His soundtracks to genres of cinema created beginning from 80 s of XX century became the fundamental contribution. They are very popular among people because they attracted attention and it was easy to remember them due to their melodious sound. A. Lunina mentions the list of his works in the field of cinematography. These works became very noticeable in the Soviet, Russian and Ukrainian cinema heritage. "Nowadays among Ukrainian composers Oleh Kyva takes the first place under the rate of employment in cinematography. He wrote brilliant music to more than fifty well-known domestic and Russian movies, serials, historic and documentary films, newsreels and cartoons. They are "The Year of Calf", "Marry-Go-Round", "Unlabelled Freight", "Hearts of the Three", "Wicked", "Doping for Angels"; Ukrainian movies "Wasted Sunrises", "Dead End", "Long Way to Mum", "Man from "Alfa" Team", "The Way to Sich", "Longer than Arrow Flow", "Cossacs Go", "Smoky Mountains", "Clarinets of Tenderness"...; serials "Countess de Monsoraue", "Faults and Their Fans", "My Personal Enemy", "The Doll", "Ash of Phoenix"...; cartoons "Old Ballad", "Poplar Tree", "Drama on the Paper". This is a very small part of the great volume of Oleh Kyva music to the movies" (Lunina, 2007).

Of course, vocal music was the main for Oleh Kyva and that is the evidence of his following the traditions of the previous Ukrainian music culture. It concerns the vocal beginning in general as well as the issue of addressing to cantata genre. There are a lot of examples of cantatas in the creation of S. Ludkevych, B. Liatoshynskyi, L. Revutskyi and other composers. In his early period of creation Kyva wrote broadscale cantatas. In 1967 Kyva created Cantata in Memoriam of Auschwitz Victims for soloists, choir and orchestra; in 1970 he created Cantata in V. Lenin Memoriam. The first work reflected timely and extremely painful topic gained personal character for all the participants while the second became the type of answer for the social realism demands. After that composer quit to create broad-scale works and began to address to chamber cantatas. Totally there were six of them. Each time he chooses the lyrics of different authors and it allows him to open absolutely different edges of lyric and sometimes tragic figurality.

The question is why the composer addressed to cantata particularly? This genre was popular among creation of many composers in the second half of XX century. $\mathrm{O}$. Komenda gives the list of cantatas created by Kyva's contemporaries. "It is evident that chamber cantata is enough up-to-date and greatly represented genre in the Ukrainian music of the second half of XX century. Actually, each Ukrainian composer has addressed to this genre at least once. For example V. Runchak "Chumaks' Songs" (for baritone and Ukrainian folk instruments ensemble, 1987), H. Havrylets "Look into Chilhood" (for soprano and chamber orchestra, 1987), Yu. Homelska "Nonwhispered Words" (for soprano, flute and piano, 1994), V. Larchykov "Night Songs" (for voice, soprano-saxophone, oboe (alto flute), violoncello, 1991), K. Tsepkolenko "Exit" (for rwoman's voice, clarinet, accordion and piano, 1996) (Komenda, 2006, p. 24). Generally, in those chamber cantatas of the second half of XX century particular 
common features are formed. Very often they use folklore elements processed taking into account modern composers' techniques.

In his chamber cantatas - No 1 on A. Novchadovska (1977) lyrics, No 2 on F. Garsia Lorca (1981) lyrics, No 3 on P. Tychyna (1982) lyrics, No 4 on O. Mandelshtam and M. Zabolotskyi (1983) lyrics, No 5 on F. Tutchev and O. Pushkin (1993) lyrics composer chooses lyrics of different poets. Chamber symphony for soprano and chamber orchestra on T. Shevchenko (1997) lyrics is close to cantata genre. In these works composer was able to release absolutely contradictious, by their figurality, themes. When we talk about such genre as cantata, which is actually a cycle work, the issue of joining separate parts together is very important. Among works where the attempts to understand the main principles of cycle were undertook it is necessary to highlight the work by L. Rappoport. Author thinks there are significant differences in the issue of keeping cycle integrity depending on national traditions and idea and stylistic directions. "In each case the investigator underlines one or two musical principles are prevalent for particular work or chamber and cantata creation of particular composer. However, usually cycle implements on the basis of the system of principles (and in chamber cantata not only musical but verbal as well), choice and combining of which fully depends on author's idea" (Manokina, 2018, p. 1).

We can follow the common feature joining first cantatas by Kyva. The first, the second and the third chamber cantatas are for one and the same cast - soprano and chamber orchestra. Woman tells us the story. The forth cantata is for the duet of soloists - soprano and baritone accompanied by chamber orchestra. The fifth cantata is for the basso and chamber orchestra. Even considering the cast we can mention the peculiarity that first we have woman voice prevailing, than there are voices of woman and man and then there is a transfer to man's voice.

At the same time, each chamber cantata by Kyva is a unique variant of this genre realization. Cantata No1 on lyric by A. Novochadivska consists of five parts - Prelude, Aria, Recitativo, Canzona and Choral. These names (except of Prelude) coincide with genre genetically connected with vocal beginning. They represent retrospection of vocal chamber works of different times and sometimes had opposite style direction. Each part contains vocal section which means that even the Prelude is localized. "Aria" part is connected with baroque style but there are also lyric intonations characteristic for variety art of XX century. "Canzona" part embodies lyric images remind us about rays of sun. The author masterly joins parts of academic and variety music art thus we can talk about creation of the unique woman's "monologue" joining different styles directions.

Cantata No2 on F. G. Lorka lyrics contains six parts where names of the parts mostly connected with instrumental genres - Prelude, Toccata, Intermezzo, Melancholy and Berceuse. This work is full of watching and particular philosophy combined with lyric and even intimate utterances. There are also different ranges connected with Spanish and Oriental melodies, rhythm, peculiarities of orchestrating (castanets, guitar) keep us closer to Spanish folk music (romances, flamenco). "Pastoral" part combines shepherds folk tunes and vocal remarks of soprano. Instrumental parts are developed more in this work because there are parts where there is no vocal at all.

Chamber cantata No3 was written also for soprano and chamber orchestra. It is the example of song and romance type of chamber cantatas. 0 . Komenda thinks that 
there are features of "classic" seen in "national tradition shown in genre and intonation details of theme and underline existing patterns of genre" (Komenda, 2006, p. 23). Author means the addressing to the material close to folk songs, using of romance intonations. Each part of cantata has the features of song and strophe form with the elements of variations. Leading Ukrainian composer Lesia Dychko, whose creation is represented by different genres (cantatas, concerts for choir and common prayers, etc.) mentioned very special talent of composer and her own passion to Chamber cantata No3. "Oleh Kyva is outstanding Ukrainian composer and his talent is unrivaled. His music touches the heart of each person. Works in this performance are extremely varied by emotions: tragedy, drama, lyrical, bright and tender... The third cantata on P. Tychyna lyrics is my favorite work by Oleh Kyva. Here he glorifies the eternal beauty and dignity of the World and tragic but magnificent and sacred glory of life. Oleh Kyva is one of the greatest composers of our time and his music penetrates people's hearts with its very sincere emotions. His art is the game of heaven spheres" (Lunina, 2007).

Chamber cantata No4 consists of three parts. First two are written on O. Mandelshtam lyrics and the third part is on M. Zabolotskyi's lyrics. The content of cantata presents us with deep philosophy thoughts about the Universe and nature, death and life. M. larko mentions that Oleh Kyva through his art analyzes and highlights ideas of thinking about the ending of human life and eagerness for eternity leading for both authors. "The main thing which is underlined by 0 . Kyva in the creation of these poets is the pathos of personal eternity which comes from persuasion that it is necessary to voluntary rule natural evolution" (Yarko, 2009, p. 60). In the first part of Chamber cantata No4 Oleh Kyva presents very interesting interpretation of the function of general form of the cycle division. H. Manokina thinks that the first part acts as an epigraph. It means that main themes and characters could be found in the chapter on the text level there are no such things at music level. "There is a conclusion that context environment and music reading of poetry affect its dramatic functions in the cycle. In Kyva's cantata section of the first part with poem by Mandelshtam presents the function of epigraph. It concentrates main characters and ideas of cantata on verbal level, but on the music and stylistic level makes the contrast with the next parts of the work and makes no influence on the further development of actions in the work" (Manokina, 2018, pp. 12-13). Specific feature of this cantata is intonation dissociation and contrasting parts on music level. In the first section theme, as far as we can interpret it as one part form as well as three parts form, we can see intonation isolation and using elements with small ambitus which remind folk beginnings, in particular, those of archaic period. They combined with episodes where there is a connection with psalms recitative. The peculiarity of composer is two-dimentionality of lyrics which could be manifested in meditation in vocal and instrumental section as well as more actively with high splash of emotions in only instrumental blocks.

The fifth chamber cantata has some common features with the forth one. There is also verbal text by two authors. Here the poems of Russian classical poets F. Tutchev and 0 . Pushkin are used. It is very important to mention that form of three parts is also common for both cantatas (fourth and fifth). Theme is connected with depicting of autumn. There are also very interesting philosophical thoughts of composer. It looks 
like composer draws pictures of nature watching, but there we see the real idea of the work. There is the problem that human existence comes to the end and that the life passes fast. "Only at the face of death we understand the reason of life and that we are mortal" (Vasylenko, 2012, p. 186).

\section{Conclusions}

Scientific novelty is in the highlighting of key features of choir thoughts of Oleh Kyva reflected in his chamber cantatas. Synthesis of different genres sources and bright melodious beginning are the peculiarities which make the basis of author composer's style. He confirms the vitality of genre in music culture of XX century and ability to implement composer's intentions.

Chamber cantata is one of the main genre in 0 . Kyva creation. We can mention the evolution of composer's thoughts on the example of his cantatas. This genre shows us changing in composer's thoughts from lyric characters prevailing in first chamber cantatas till philosophically deep thoughts in the last. Composer has the inclination to mix styles and combines elements of academic and variety art music, domestic folklore and oriental ethnic music. Each chamber cantata is the new variant of this genre implementation and witnesses about great melody talent of composer. Specific of embodying of this genre in other leading Ukrainian composers is the perspective direction of further studying.

\section{References}

Komenda, O. (2006). Kamerna kantata v ukrainskii muzytsi 2-i polovyny XX st. Osnovni napriamky i tendentsii rozvytku zhanru [Chamber cantata in Ukrainian music of the second half of the twentieth century. The main directions and trends of the genre]. Problemy pedahohichnykh tekhnolohii, 1(31), 22-26 [in Ukrainian].

Lunina, H. (2007, July 25-31). Vymiry muzychnoi krasy [Measures of musical beauty]. Ukrainske slovo [in Ukrainian].

Manokina, H. V. (2018). Problema tsyklizatsii u zhanri kamernoi kantaty (na prykladi tvoriv Yeleny Firsovoi) [The problem of cyclization in the genre of chamber cantata (based on the works of Elena Firsova). (Abstract of PhD Dissertation). Ukrainian National Tchaikovsky Academy of Music, Kyiv [in Ukrainian].

Vasylenko, O. (2012). Osoblyvosti zhanru kamernoi kantaty Oleha Kyvy v konteksti kompozytorskykh poshukiv suchasnosti [Features of Oleh Kiva's chamber cantata genre in the context of the composer's search for the present]. Kyivske muzykoznavstvo, 41, 177-187 [in Ukrainian].

Yarko, M. I. (2009). Ukrainska kamerna kantata: invariant zhanrovoi formy [Ukrainian chamber cantata: invariant of genre form]. Drohobych: Drohobych Ivan Franko State Pedagogical University [in Ukrainian]. 


\title{
КАМЕРНІ КАНТАТИ ОЛЕГА КИВИ: СТИЛЬОВА ЕВОЛЮЦІЯ ЖАНРУ
}

\author{
Наталія Перцова ${ }^{1 a}$, Вікторія Шевченкоa \\ 'доцент; ORCID: 0000-0003-4575-7691; e-mail: natalia.pertsova@gmail.com \\ ${ }^{2}$ доцент \\ аКиївський національний університет культури і мистецтв, Київ, Україна
}

\section{Анотація}

Метою дослідження $є$ виділення характерних рис композиторського мислення Олега Киви на прикладі його камерних кантат. Дана мета передбачає вирішення ряду завдань, зокрема, аналіз місця його творчості в контексті музичної культури другої половини XX століття та виокремлення його зв'язків з попередньою музичною традицією.

Методологія дослідження пов'язана з використанням методу аналізу наявного музичного матеріалу - кантат О. Киви, здійснення огляду науково-теоретичного матеріалу, присвяченого творчості композитора та узагальненню і систематизуванню отриманих результатів з метою виділення спільних та відмінних рис кантат Киви.

Наукова новизна полягає у висвітленні ключових рис хорового мислення Олега Киви, які унаочнюються у його камерних кантатах. Синтезування різних жанрових витоків та яскраве мелодичне начало $є$ тими особливостями, що становлять основу композиторського стилю автора. Утверджується життєвість жанру кантати у музичній культурі XX століття та його спроможність відтворити композиторські інтенції.

Висновки. Камерна кантата $є$ одним з провідних жанрів у творчості О. Киви. Можна відмітити еволюцію композиторського мислення на прикладі його камерних кантат. В даному жанрі простежується зміна композиторського мислення - від превалювання ліричних образів у перших камерних кантатах до філософськозаглибленої споглядальності в останніх. Для композитора притаманна схильність до стильового синтезу, що проявляється шляхом поєднання елементів академічної та естрадної музики, вітчизняного фольклору та східної етнічної музики. Кожна камерна кантата являє собою новий варіант реалізації даного жанру та свідчить про надзвичайну мелодичну обдарованість композитора. Перспективним напрямком для подальших розвідок виступає висвітлення специфіки втілення даного жанру у творчості й інших провідних українських композиторів.

Ключові слова: камерні кантати; Олег Кива; стиль; еволюція; лірика 


\title{
КАМЕРНЫЕ КАНТАТЫ ОЛЕГА КИВЫ: СТИЛЕВАЯ ЭВОЛЮЦИЯ ЖАНРА
}

\author{
Наталья Перцова'а , Виктория Шевченкоª \\ 'доцент; ORCID: 0000-0003-4575-7691; e-mail: natalia.pertsova@gmail.com \\ ${ }^{2}$ доцент \\ ${ }^{a}$ Киевский национальный университет культуры и искусств, Киев, Украина
}

\begin{abstract}
Аннотация
Целью исследования является выделение характерных черт композиторского мышления Олега Кивы на примере его камерных кантат. Данная цель предполагает решение ряда задач, в частности, анализ места его творчества в контексте музыкальной культуры второй половины XX века и выделение его связей с предыдущей музыкальной традицией.
\end{abstract}

Методология исследования связана с использованием метода анализа имеющегося музыкального материала - кантат О. Кивы, осуществления осмотра научно-теоретического материала, посвященного творчеству композитора, обобщению и систематизации полученных результатов с целью выделения общих и отличительных черт кантат Кивы.

Научная новизна заключается в освещении ключевых черт хорового мышления Олега Кивы, которые проявляются в его камерных кантатах. Синтезирование различных жанровыхистоков и яркое мелодическое начало являются теми особенностями, которые составляют основу композиторского стиля автора. Утверждается жизненность жанра кантаты в музыкальной культуре XX века, и его способность воплотить композиторские интенции.

Выводы. Камерная кантата является одним из ведущих жанров в творчестве О. Кивы. Можно отметить эволюцию композиторского мышления на примере его камерных кантат. В данном жанре прослеживается изменение композиторского мышления - от превалирования лирических образов в первых камерных кантатах к философско-углубленной созерцательности в последних. Композитору присуща склонность к стилевому синтезу, которая проявляется за счет сочетания элементов академической и эстрадной музыки, отечественного фольклора и восточной этнической музыки. Каждая камерная кантата представляет собой новый вариант реализации данного жанра и свидетельствует о чрезвычайной мелодической одаренности композитора. Перспективным направлением для дальнейших исследований выступает освещение специфики воплощения данного жанра в творчестве и других ведущих украинских композиторов.

Ключевые слова: камерные кантаты; Олег Кива; стиль; эволюция; лирика 